\section{The practice of complementary feeding among stunted children under the age of two}

\author{
Inne Soesanti, ${ }^{1}$ Pinky Saptandari, ${ }^{2}$ Sri \\ Adiningsih, ${ }^{3}$ M. Bagus Qomaruddin ${ }^{4}$ \\ ${ }^{1}$ Public Health Program, Faculty of \\ Public Health; ${ }^{2}$ Department of \\ Anthropology, Faculty of Social Science \\ and Political Science; ${ }^{3}$ Department of \\ Health Nutrition; ${ }^{4}$ Department of Health \\ Promotion and Behavioral Science, \\ Faculty of Public Health, Universitas \\ Airlangga, Surabaya, Indonesia
}

\begin{abstract}
Stunting is caused by chronic malnutrition and recurrent infectious diseases. Stunting in Pasongsongan Village affects less than $20 \%$ of the children under two, leading to problems in growth in early childhood. Ocean fish is the main animal products in this village on the coast, but it turned out that it is not served to the children, even if they should have begun to be introduced to animal products by the age of 9 months. The purpose of this study was to observe the practices of complementary feeding among stunted children under the age of two in Pasongsongan Village. This research was carried out by qualitative method. The informants were twelve mothers of children under the age of two. Data was collected from interviews, observations and documentation. The stunted children only consumed rice porridge until the age of one, which means that the food intake contains mostly carbohydrates. The mothers who have stunted children have argued that the children's intestines is not strong enough to digest food with coarser texture like eggs, fish, beef and chicken. Sea fish are given when the children can walk because there has long been a belief that fish contain worms. No feeding fishes and other animal products that are good source of protein can affect their growth in a negative way. The feeding practice of stunted children under the age of two in Pasongsongan Village was strongly influenced by culture. The mindsets of mothers of the stunted children regarding feeding practices must be changed.
\end{abstract}

\section{Introduction}

Stunting is a nutritional status based on an indicator of Length-for-Age $(\mathrm{PB} / \mathrm{U})$ or Height-for-Age (TB/U). Comparing nutri- tional status based on length/height-for-age to the standard of the WHO Multicentre Growth Reference Study (MGRS) in 2005, young child are defined as stunted when the $\mathrm{Z}$-score is less than -2SD, and are defined as very short (severely stunted) if the Z-score is less than -3SD. ${ }^{1}$

Routine check-up where children's growth is measured is needed as a part of chidren's health observation and can help to detect stunting.

Stunting occurs even in the womb, if pregnant women suffer from malnutrition and during the first two years of a child's life or the first 1000 days of life. ${ }^{2}$ The cause of stunting is lack of nutritional intake to support the growth and development of infants and children, and such children are more susceptible to suffer of infectous diseases during their early life. . $^{3,4}$

Adults who were stunted are characterized by short stature, have poor cognitive performance and underperform at school, ${ }^{5}$ leading to poor school attendance. As adults, stunted children continue to show risk for lower intellectual functioning and degenerative diseases. ${ }^{4}$ According to Shrimpton, children are at risk when they show short stature before the age of two. Therefore, they need to receive correct treatment during the first two years of life. ${ }^{4}$

Based on Indonesia Basic Health Research (RISKESDAS), stunting occurrence declined from $37.2 \%$ to $30.8 \%$ between 2013 and $2018 .^{6}$ Though there is a decrease, over $30 \%$ of population is affected by stunting, making it an alarming health problem that must be addressed. Furthermore, there are less than $16 \%$ of stunted children under 5 in Pasongsongan Village, which is lower than the figures reported by 2013 RISKESDAS. They have suffered chronic malnutrition during early stages of children growth.

Pasongsongan Village is a coastal area in which the dock for trading marine fish landed in the port. The village is located on the coast and this should have facilitated the residents to acquire protein, an important nutrient for growth, from animal sources such as fish, squid, shrimp, and crabs. There should not have been stunted children given the geographical location.

In 2016, a preliminary study was conducted using survey of diet and nutrition which was further examined with semiquantitative method. We conducted a survey of 5 non-stunted toddlers and 7 stunted toddlers in the Pasongsongan Village. The result indicates that the non-stunted toddlers consume various types of food and the level of intake meets the requirement of Recommended Dietary Allowance. On the other hand, the types of food consumed by
Correspondence: Inne Soesanti Public Health Doctoral of Program, Faculty of Public Health, Universitas Airlangga, Kampus C Mulyorejo, Surabaya 60115, Indonesia.

Tel: +6282230070342

E-mail: insantie@gmail.com

Key words: Stunting, complementary feeding, under the age of two years old.

Contributions: IS did research and presented at the INSBIOMM conference. PS, SA, MBQ acted as supervisors of this study.

Conflict of interest: The authors declare no conflict of interest.

Funding: None.

Acknowledgements:The authors grateful the Sumenep Regency Government for having allowed the research in Pasongsongan Village, Pasongsongan District.

Conference presentation: This article has been presented at International Conference of Infections Diseases, Biothreats, and Military Medicine (INSBIOMM), 2019.

Received for publication: 17 February 2020. Accepted for publication: 1 July 2020.

This work is licensed under a Creative Commons Attribution-NonCommercial 4.0 International License (CC BY-NC 4.0).

(Copyright: the Author(s), 2020

Licensee PAGEPress, Italy

Infectious Disease Reports 2020; 12(s1):8723 doi:10.4081/idr.2020.8723

the stunted children are mainly lontong (a food made from rice wrapped in banana leaves and cooked by steaming) with banana, rice porridge, broth from fish stew or vegetable soup poured over lontong, with no serving of vegetable or any type of side dish. Fish dishes are only given once they are one or two years old, and even then less than 50 gr. It can be concluded that the average amount of food consumption and nutrition does not meet the requirements of the Recommended Dietary Allowance as it contains mostly carbohydrates and water. Their diet lacks nutrition, diversity, and quantity. The growth retardation happens during this complementary feeding period: ${ }^{2}$ this study aims to observe the practice of complementary feeding in stunting children under the age of two.

\section{Materials and Methods}

This study was carried out by qualitative method. Stunting children under the 
age of two years were identified by measuring length for age compared to the WHOMGRS. The informants of this research were mothers of stunted children of under 2 years olds. The informants were selected by purposive sampling and amounted to 12 informants. Informants in this study are the mothers or grandmothers who prepare and provide food to stunting children under two years old. This was ascertained by asking the mothers of the stunted children under two years old before the interview. If the mother said that the child's grandmother used to provide food, then the grandmother was interviewed instead. When the mother used to provide food for the child herlesf, then the mother was interviewed. Data was collected from interviews, observations and documentation. Observations were made during the researcher's visit to the informants' houses, such as when the mother prepared and gave food. The researcher documented what was done by the informants and added further observations and other documentations.

The research was conducted in Pasongsongan Village, District of Pasongsongan, in the northern part of Sumenep, East Java. Its geographical features comprise coasts and highland. The interview instrument contained a list of questions about the provision of complementary food to the stunted children, such as the type of food, the frequency of feeding, reasons for the food choice, the age of feeding, and other dietary restrictions.

\section{Results and Discussion}

The twelve stunted children under the age of two who were the subjects of the study were between 11 months and 23 months, males and females. Stunting is detectable from the nutritional status assessment by measuring length or height for age compare WHO standard. According to the nutritional status for length/height for age of the twelve children, 10 children showed a nutritional status of $<-2$ SD categorizing stunting, and 2 children with of $<-3$ SD categorizing severe stunting.

Based on interviews, all children had suffered from fever, cough, influenza and diarrhea. Two children had been hospitalized because of diarrhea and typhus.

The mother's condition is generally healthy and rarely sick. Mothers routinely bring their children to the posyandu for getting immunized, getting vitamins supplements or get monitored for growth, and went to a shaman to massage their children and for getting jamu cekok (herbal medicine).

\section{Concept of food}

The residents of Pasongsongan Village consider food what fills up the stomach or what leaves them with a pleasant and satisfied feeling after eating. Main courses are typically corn rice, white rice, and lontong. Lontong is a food made from rice wrapped in banana leaves and cooked by steaming. Porridge is also introduced as first meal for babies and children. The community mention "side dish" with the word "fish" for example tempeh fish, tofu fish, chicken fish, egg fish, meat fish, while sea fish are called cukok tasek. The term "vegetables" refers to any sautéed vegetable, that is, fried vegetables with a little hot oil. A type of dish prepared by boiling vegetables and/or other ingredients is referred to as "stock", not "soup". They consume Moringa broth, clear broth, spinach broth, soup broth, soto broth, and bakso broth.

An informant, Js, stated that:

"Food is something what fills up the stomach. We usually eat corn rice or white rice with fish. If the food provided does not use fish, the name is not eat yet. There must be a dish served, like ocean fish, eggs, tofu, tempeh, or chicken. While vegetables must not absolutely present. If we cook moringa broth the side dish must be cukok tasek (ocean fish). Otherwise, it does not taste as good."

From the statement above, it can be concluded that a typical meal is rice with a side dish; or else it is not considered a meal. Any type of side dish should always be served every meal, while vegetables or broth are complementary.

\section{Food prohibitions for children under the age of two}

A food taboo is a prohibition against consuming certain foods and is based on the idea that these foods may trigger any unexpected or dangerous reaction. Children under one are only given soft and delicate food like porridge because their intestines are deemed unable to digest food with coarser texture, as stated by Ms. Al below:

"Children are given porridge until the age of twelve months. Child's intestine is not strong enough to digest rough food. I worry about my kid having stomach ache. By 12 months, my child can be fed rice and eggs. From nine to twelve months olds, my child given mashed potatoes mix in porridge, sometimes with a little stock, sometimes without."

The statement above emphasizes the restrictions against eating food with coarser texture for kids younger than twelve months. Only porridge is allowed as babies' meal. One cause for concern is that the children may suffer from stomach pain because their intestines are not strong enough to digest food with coarser texture.

Children under the age of one or two are also prohibited from consuming ocean fishes due to fear of infected of worms. An informant, Ms. Mi, said that:

"My child was introduced to fishes at the age of fifteen months, because she has been able to walk. When she was not able to walk yet, she must not be given ocean fish because my mother forbade it for fear of my child getting intestinal worm. So I do not normally serve it to my child and I only give porridge until they can walk."

The statement above emphasizes the restriction against eating ocean fishes for younger children who can not walk yet. Once they can walk, a wider variety of food is introduced. Nutrient-dense foods should not have been avoided in this manner.

Food prohibitions was done by mothers that can lead to malnutrition due to various beliefs. This cultural belief and food prohibitions can limit the utilization of available food resources and eventually lead to malnutrition in children. ${ }^{7}$

\section{The practice of feeding children under two}

Mothers of stunted children under two began introducing porridge as complementary food for their infants from the age of five or six months and continued to serve it solely until the age of eight or twelve months. A certain brand of brown rice-flavored, mung bean-flavored, and banana-flavored porridge became the first solid food for infants aged five to eight months old. Following the instructions on the package, one serving is prepared from mixing two tablespoons of powdered porridge with warm water or liquid milk. The babies could eat about twice or three times a day. Four informants told the researcher that they began introducing bananas to their sixmonth-old or nine-month-old babies. Mashed bananas were served occasionally once a day during the day.

The practice of feeding ninemonth-old to twelve-month-old babies varied. For breakfast, an informant served rice porridge called tajin. Tajin was porridge made of rice without coconut milk. Another informant prepared mung bean-flavored, brown rice-flavored or banana-flavored porridge. During the day, the meal is either porridge with mashed potatoes or the stock of moringa, broth of soup, broth bakso, broth of cakalan fish, broth of chicken soto, 
or spinach broth poured over mashed lontong. Informan $\mathrm{K}$ give statement below:

"Daughter of my grandchild is given jamu cekok because she refuses to eat. She was given food at the age of five months, like SUN porridge twice a day in different flavors: mung beans, brown rice, or bananas so as not to get bored. At the age of 8 months, he was introduced to lontong with broth moringa, broth of soup for lunch and dinner. Occasionally he had tajin for breakfast."

It can be highlighted from the statement above that her grandchild begun complementary feeding at the age of five months. She was fed porridge twice a day. At the age of eight months, her grandchild was fed lontong with broth moringa or soup twice a day, porridge and tajin for breakfast. The babies' food intake contain mostly carbohydrates from rice and its mostly processed products.

In addition to food, according to tradition, traditional herbs (jamu cekok) must be given to children under two years old. Jamu was given with the aim of making the child healthy and increase appetite. Jamu is specifically served after a massage session by a masseuse or a shaman baby (dukun bayi). The frequency of consumption varies over ages. During the first six months of babies' life, the herbs should be taken once to twice a week. After that, the frequency decreases to only once every fortnight or month. Some kids even take the supplement only when they refuse to eat because one main ingredient of the herbs is temu ireng, which is well-known to be able to increase appetite.

According to other informant, the complementary feeding of their children began with the introduction of porridge or lontong with broth moringa or soup, without any side dishes like tofu, tempeh, eggs, meat and sea fish because the child was not yet 1 year old. When children are 1 year old, they start to be given side dishes, because of the tradition recommend feeding fish or side dishes only after children are 1 year old. Informan Un give statement below:

"Before 14 months, $i$ do not give fishes for my kid because i am worried my kld will get intestinal worms. I just give him porridge at the age of 5 months until 12 months twice or three times a day. Recently, tofu, tempeh, and eggs are introduced to my kid. He likes them all. He quite likes fishes. Egg and chicken too. When i give him porridge, no side dish is served."

The above description emphasizes that before the age of 14 months children was not given fish for fear of being infected by worms, according to the myth that developed in the Pasongsongan Village community. After the 14-month-old child is given fish but only a little, because they are still afraid of children exposed to intestinal worms if they are given a lot of fish. Porridge was fed at the age of 5 months until 12 months, frequency twice-three times a day. Food intake mostly contain carbohydrat.

Informants on average introduce complementary feeding at the age of 4 or 5 months in the form of porridge. This shows that complementary feeding was given earlier than recommended by $\mathrm{WHO}^{8}$ and it is the same as in India ${ }^{9}$ Complementary food given to stunted children two years old are typically porridge, lontong, and broth, which contain mostly carbohydrates. The false belief about animal and plant protein sources having a coarse texture that may cause stomach pain if given to children under two years old causes caregivers not to provide these types of food to stunted children under two years old and prevents them from having nutrient-dense foods earlier. After the age of twelve months, it is considered late to start to consume animal and plant protein sources which should have been introduced at nine months. As infants grow and get older, breast milk alone falls short of supplying the full nutritional requirements. This is where complementary food plays a critical role in providing additional nutrients for them, especially animal protein sources must be given because it is very important for children's growth. ${ }^{10-13}$ Children need amino acid for growth because another study conveys that stunting children lack amino acid in their diet. ${ }^{14}$

They avoid serving ocean fishes until the kids are two years old because they believe that fishes can cause intestinal worms to the children. The first two years is a critical period of growth. Prolonged lack of protein, a nutrient required for growth, is one of the factors associated with stunting among children under two years old. This cause and effect relationship was illustrated in the practice of complementary feeding among stunted children under two years old in Pasongsongan Village.

\section{Conclusions}

Informants on average feed at the age of 4 or 5 months in the form of porridge. Feeding porridge until the age of 12 months with a frequency of two or three times a day or given in the morning alternating with tajin, afternoon and evening given lontong and broth soup. After the age of twelve months, it is considered too late to start to consume animal and plant protein sources which should have been introduced at nine months old because nutritional needs increase at that age. The food taboo in Pasongsogan Village prevents younger children from consuming various sources of dietary protein. This cause and effect relationship was illustrated in the practice of complementary feeding among stunted children under two years old in Pasongsongan Village.

The practice of feeding stunted children in Pasongsongan Village illustrated that the complementary food provided for them contain mostly carbohydrates and less protein and other nutrients. This is due to the strong taboo culture of eating fish and the culture of giving porridge or lontong given to children until the age of one year. Parents tend to follow the culture of society in providing complementary food to their children. The food taboo in the community that prevents from serving ocean fishes and comes up with solely porridge or lontong for infants under two years old can result in protein deficiency and growth becomes stunted.

\section{Suggestions}

Counseling to educate parents on complementary feeding practices must be provided as one way to prevent stunting. The community needs to be fully informed of what food are nutrient-dense and can supply the full nutritional requirements along with some practical ways to prepare them so as to tackle the food taboo they have long been believed and to change the mindset of mothers of stunted children under two years. Mothers' assumption based on their culture that the child's intestine is not strong enough to receive coarse-textured food at the age of 8 or 9 months needs to be corrected by providing knowledge about proper breastfeeding complementary feeding practices so that mothers can provide MP-ASI correctly and appropriately.

\section{References}

1. Nutrition Landscape Information System: Help Content. Available from: https://apps.who.int/nutrition/landscape /help.aspx?menu=0\&helpid=391\&lang $=$ EN Accessed : February 2020

2. Dewey KG, Begum K. Long-term consequences of stunting in early life. Matern Child Nutr 2011;7:5-18.

3. Frongillo EA. Symposium: Causes and 
Etiology of Stunting. Introduction. J Nutr 1999;129:529S-530S.

4. Victora CG, Adair L, Fall C, et al. Maternal and child undernutrition: consequences for adult health and human capital. Lancet 2008;371:340 57.

5. Grantham-McGregor S, Cheung YB, Cueto $\mathrm{S}$, et al. Developmental potential in the first 5 years for children in developing countries. Lancet 2007;369:60-70.

6. Dinkes. Hasil Utama Riset Kesehatan Dasar Jawa Timur 2018. Jakarta Badan Penelit dan Pengemb Kesehatan, Kementrian Kesehat Republik Indones 2018;1-82.

7. Foster G, Anderson B. Antropologi
Kesehatan. Jakarta: UI-Press; 2009.

8. WHO. Global strategy for infant and young child feeding. Fifthy-fourth world Heal Assem 2001;5.

9. Aggarwal A, Verma S, Faridi MMA, Dayachand. Complementary feeding Reasons for inappropriateness in timing, quantity and consistency. Indian J Pediatr 2008;75:49-53.

10. Hoppe C, Udam TR, Lauritzen L, et al. Animal protein intake, serum insulinlike growth factor I, and growth in healthy 2.5-y-old Danish children. Am J Clin Nutr 2004;80:447-52.

11. Osman A. Effects of childhood malnutrition on Insulin-like Growth Factor-1 (IGF-I) and IGF-Binding Protein-3 levels: A Malaysian and New
Zealand analysis. Vol. 6, Asia Pacific Journal of Clinical Nutrition. 1997: pp. 273-6.

12. Headey D, Hirvonen K, Hoddinott J. Animal sourced foods and child stunting. Am J Agric Econ 2018;100: 1302-19.

13. Darapheak C, Takano T, Kizuki M, et al. Consumption of animal source foods and dietary diversity reduce stunting in children in Cambodia. Int Arch Med 2013;6.

14. Semba RD, Shardell M, Sakr Ashour FA, et al. Child Stunting is Associated with Low Circulating Essential Amino Acids. EBioMedicine 2016;6:246-52. 